\title{
Long Non-Coding RNA ASB I6-ASI Functions as a miR-760 Sponge to Facilitate the Malignant Phenotype of Osteosarcoma by Increasing HDGF Expression [Retraction]
}

Yin R, Liu J, Zhao D, Wang F. Onco Targets Ther. 2020;13:2261-2274.

The Editor and Publisher of OncoTargets and Therapy wish to retract the published article. Concerns were raised regarding the alleged duplication of images in Figures $2 \mathrm{C}$, $4 \mathrm{~B}$ and $6 \mathrm{~B}$ with similar images from unrelated articles, specifically:

- Figure 2C, panel U2OS si-ASB16-AS1 appears to have been duplicated with a similar image in Figure 6C, panel Huh7 si-GAS6-AS+NC inhibitor from Ai et al, 2020 (https://doi.org/10.1080/ 15384101.2020.1729323).

- Figure 4B, panels HOS agomir-NC; agomir-760 appear to have been duplicated with similar images in Figure 6C, panel Sw1990 miR-769 mimics + pcDNA3.1-ETS1 and 5C, panel Panc-1 si-ETS1, respectively from Cheng et al, 2020 (https://doi.org/ 10.2147/OTT.S218876).
- Figure 6B, panel U2OS si-NC appears to have been duplicated with similar images in Figures 5C, panel H522 NC siRNA from Kang et al, 2019 (https://doi. org/10.2147/OTT.S204004) and 3D, panel siHAND2-AS1 from Yu et al, 2020 (https://doi.org/ 10.2147/OTT.S233256), respectively.

The authors responded to our queries but were unable to provide an explanation for the alleged image duplication and could not provide the original raw data or ethics approval documents for their study and have therefore agreed to retract the article.

Our decision-making was informed by our policy on publishing ethics and integrity and the COPE guidelines on retraction.

The retracted article will remain online to maintain the scholarly record, but it will be digitally watermarked on each page as "Retracted".

\section{Publish your work in this journal}

OncoTargets and Therapy is an international, peer-reviewed, open access journal focusing on the pathological basis of all cancers, potential targets for therapy and treatment protocols employed to improve the management of cancer patients. The journal also focuses on the impact of management programs and new therapeutic

agents and protocols on patient perspectives such as quality of life, adherence and satisfaction. The manuscript management system is completely online and includes a very quick and fair peer-review system, which is all easy to use. Visit http://www.dovepress.com/ testimonials.php to read real quotes from published authors. 